\title{
The Tyrannies of Distance: From Cairns to the Melbourne International Comedy Festival
}

\author{
Pauline Sherlock
}

James Cook University

\begin{abstract}
Stand-up comedians need performance opportunities in order to hone their skills and develop confidence as performers. Living in Cairns, a long distance from a major comedy centre, poses problems in gaining practice and exposure as an emerging stand-up comedian. This article considers the process and outcomes of staging a stand-up comedy show in the Melbourne International Comedy Festival of 2015. The value of this experiment in providing performance opportunities which contribute to developing the skills and confidence of a stand-up comedian is explored. An auto ethnographic process has been utilised together with heuristic research to develop a case study. Observations are limited to the experiences of the researcher and the expressions, during interviews, of comedians. Staging the show in the Melbourne International Comedy Festival was challenging in many ways and expensive. The experience of being in Melbourne during the comedy festival, performing in varying situations and meeting with other comedians did provide valuable lessons, both positive and negative. This paper may serve to inform stand-up comedy performers from regional areas regarding staging a show at the Melbourne International Comedy Festival and of the benefits and hazards of doing so.
\end{abstract}

Key Words: Stand-up comedy, deliberate practice, Melbourne International Comedy Festival, expertise, experiential learning.

\section{Introduction}

C tand-up comedians need performance opportunities in order to hone their skills and develop confidence as performers. The regional city of Cairns in Tropical North Queensland, Australia, provides a seemingly idyllic environment. Surrounded by beautiful, natural landscapes, the climate is mild for much of the year and the living is generally peaceful and easy without the rush and bustle of a city setting. Cairns, however, is a long distance from a major comedy centre, which poses difficulties in gaining practice and exposure for an emerging stand-up comedian. In this paper I discuss the process and outcomes of staging a stand-up comedy show in the Melbourne International Comedy Festival of 2015. I explore the value of this experience in providing performance opportunities which contribute to developing the skills and confidence of a stand-up comedian. I discuss the importance of deliberate practice along with perceptual and experiential learning with relation to the pursuit of expertise in stand-up comedy.

\section{The Quest for expertise}

In the quest for expertise in any chosen field, the learning and development of skills is required. Chase and Simon proposed that the attainment of expert performance was the 
result of many years of experience in "any skilled task" accumulating vast amounts of knowledge and "pattern based retrieval mechanisms" (cited in Ericsson, 1996, p. vii). In a study of expertise in chess players, Simon and Chase found that it took at least a decade to attain the level of a Grand Master (cited in Ericsson, Krampe \& Tesch-Romer, 1993, p. 366). Hayes showed that, in order to develop the abilities and maturity to compose outstanding music, more than ten years was necessary (cited in Ericsson, 1996, p. vii). This "ten year rule" is also supported by many subsequent studies in other disciplines (Gladwell cited in Russo, 2009, p. 43). In their 1993 study of violinists and pianists, Ericsson, Krampe and Tesch-Romer found that though this experience is essential, expertise was not attained as an automatic result of that experience. They argued that a considerable effort along with the guidance from instructors and coaches was necessary and that invariably, those that achieved the highest levels of expertise had accumulated over ten thousand hours of deliberate practice (p. 392). Deliberate practice is defined by Gladwell "...systematic, intensive, feedback-rich, and focused application to a specific task" (cited in Russo, 2009, p. 64)

Gladwell also confirms what is known as the "ten thousand hour rule":

The idea that excellence at performing a complex task requires a critical minimum level of practice surfaces again and again in studies of expertise. In fact, researchers have settled on what they believe is the magic number for true expertise: ten thousand hours (cited in Russo, 2009, p. 43).

\section{Deliberate Practice for a stand-up comedian}

For the Stand-up comedian deliberate practice is a more complex dilemma than for those able to engage in solitary preparation. Comedian, Judah Friedlander ("Advice for comedians") articulates it well:

It's not like guitar; you can sit at home, practice your guitar and get great. You can only get good at stand-up by doing stand-up, you have to have an audience, so you have to practice and it's good to practice in front of good crowds and bad crowds.

While a comedian can sit at home and write comic material it is very difficult to know if that material is funny or who might find it funny without performing it to others. As an emerging performer, it is particularly difficult to know what material will work, until it is tried out in front of some form of an audience, whether it is a friend or strangers in a comedy club. Once experience is gained on the stage and some level of confidence is found through practice, material can be crafted with more assurance. Nonetheless, professional comedians still continue to try out new material at what is known as 'open mic nights' or amateur nights.

During interviews conducted with two seasoned professional comedy performers, Mike Goldstein (Personal communication, April, 2015) and Lawrence Mooney (Personal communication, April, 2015), they emphasised the need to try new material out in a variety of environments, and with a variety of audiences. Even a world renowned comedian of the stature of Jerry Seinfeld has to start at the beginning and build up the hours of performance necessary to attain expertise on the stage as a stand-up comedian. After a long hiatus from performing stand-up material, Seinfeld's journey back to the profession is documented in his 
2002 documentary, Jerry Seinfeld: Comedian. It is very reassuring as a novice comedian to watch him struggle with difficult material and difficult audiences, taking his scraps of paper with his jokes written upon them on to the stage and stumbling through as he refines his routines to develop his new act. As a stand-up comedian these opportunities to perform through deliberate practice involve perceptual or experiential learning.

\section{Learning from experience}

Reading books about writing stand-up comedy, interviews with comedians and watching others perform can provide great insights and understanding of how to accomplish becoming a stand-up comedy performer. Through my own experience, I have found that this form of enquiry can accelerate learning. However, this can only form a theoretical basis and it is not until the act of performing is experienced that the nature of the beast can really be understood. "Knowledge is continually derived from and tested out in the experiences of the learner" (Kolb, 1984, p. 27) and for a stand-up comedian that is on a stage in front of an audience. Achieving expertise as a Stand-up comedian is reliant upon access to performance experiences with an audience. It is not sufficient, however, to get up on the stage and simply repeat material in a rote fashion without relating to the audience.

Perceptual learning can be defined as; "an increase in the ability to extract information from the environment, as a result of experience and practice with stimulation coming from it" (Gibson, cited in Kellman and Garrigan, 2009, p. 55). Therefore, to make progress and learn from performing, deliberate effort over time is required to become attuned to reactions of the audience and to develop the material in accordance. These abilities to react may be referred to as instinctive but the 'instinct' has been developed through perception and experience. Access to these performance opportunities is limited in Cairns and the distance to a 'comedy scene' exacerbates the difficulty in gaining experience.

\section{The tyranny of distance}

Distance is as characteristic of Australia as mountains are of Switzerland. [...] Australians have always recognised that distance or isolation was one of the moulds which shaped their history. (Blainey 2001, ix)

The phrase the tyranny of distance was coined by Geoffrey Blainey, in his book of the same name, tracing the effect distance and isolation has had on events that have shaped Australian history and the Australian psyche. From the time of the arrival of the first Europeans, the far north tropics of Australia have attracted explorers, scientists, naturalists and artists (Searle, 1991, p. 15). The attraction of exotic environments, botanical investigation, gold exploration, and pastoral development have all contributed to opening up the far north of Queensland to the progress of settlement and increased population (Searle, 1991, p. 14). Tourists travel from all over the world to visit this beautiful part of Australia which I have lived in for more than twenty years. This is where I have raised my children and it has provided a lovely environment for them to grow up and go to school and I have enjoyed the laid back life style and opportunities this regional city has afforded me.

Recently, however, I have been in pursuit of becoming a stand-up comedian and find the distance from a major city comedy scene a hindrance. I am not the only one to find this distance an issue. In a study of artists living in Cairns, C. Williams (2013) found that a 
major inhibitor was distance which led to high travel costs and the expense of exporting works outside the region (p. 3). While the environment and lifestyle of Cairns is inspirational for artists, the isolation can limit opportunities to networking and access to lucrative markets in larger cities (Williams, 2013, p. 3). Stand-up comedy performers do often come to Cairns but these are usually seasoned performers and celebrities with established audiences and they perform in concert venues which are out of reach to fledgling performers.

In spite of these issues, for several years I have been attempting to establish praxis for comedy performance. Coinciding with developing a theoretical understanding of stand-up comedy I have also been performing it. In 2013, as part of my Honours degree, I staged an original show called The Perils of Pauline, which included songs and comedy routines. Subsequently, I had opportunities to perform at several private events and open as a support act for a visiting comedian but there were limited occasions available to keep my hand in or should I say "to keep my mouth in". The key concern for me was self-confidence. A big part of the difficulty as an emerging comedian is having venues which are sympathetic to trying out new comedy material and having an audience which is educated to some degree about this process of performing and working through routines. Eman El-Husseini, producer of Yuk Yuk's Montreal open mic night states that "open mic is where comedians can explore and the audience members should come here with an open mind, an open mind for an open mic."

While Cairns has a vibrant live music scene and several open mic venues for anything from original song writing to Jazz there are no dedicated comedy venues, making it a difficult environment for practicing comedy. Melinda Norris ran The Sit Down Comedy Club in Cairns for two years in 2011 and 2012 and found it quite a challenging process to run these events. Although she had always thought Cairns was perfect for a comedy cabaret club, she points out that "it seemed hard to show the venue managers of this town the long term vision and for them to see the long term benefits" (Personal communication, September 12, 2015). Currently, the nearest place for comedy performance practice is in Townsville with a once a month comedy club night and the only alternative is the music open mic nights in Cairns.

Performing at music open mic nights is accessible to me since I do perform some musical numbers; however, at the point of development that I was at earlier this year, previous to the Melbourne Comedy Festival, I was not confident enough to tackle those environments. When giving advice, to a young comedian who told of how he had bombed at a music open mic night, Comedian Marc Maron, points out that “... it's not the right venue!” He suggests "It's hard, where you're at [as a beginner], and you weren't performing in, essentially, a comedy environment, so give yourself a break!" ("On bombing in comedy clubs"). In spite of the difficult nature of these music events, I determined that I would develop the skills to handle any venue; with any audience, therefore I aimed to accelerate my development as a stand-up comedian.

In cities around the world there are many opportunities to practice the art of Stand-up comedy. In New York City there are approximately fifty-nine comedy clubs most of them offering amateur spots and open mic nights. In Montreal there are about eighteen clubs, in Edinburgh there are four and in London around forty-seven. In Melbourne there are more than ten comedy clubs and one big comedy festival. Thus, in order to develop the confidence and build upon the skills and experience I had already gained, I created a research design which included performing at The Melbourne International Comedy Festival. 


\section{The self in research}

This research is guided by the qualitative method of auto-ethnography. "Autoethnography is ethnographic inquiry that utilizes the autobiographic materials of the researcher as the primary data." (Chang, 2007, p. 1) Performance autoethnography uses the self as subject and provides a rigorous, critical framework from which to describe and explore the writing and performance of reflexive comedy (Denzin, 2003, p. x; Spry, 2011, p. 498; ReedDanahay, 1997, p. 1; Sparkes, 2002, p. 210). Laurel Richardson (cited in Denzin, 2003, p. 121) offers the five criteria of; substantive contribution, aesthetic merit, reflexivity, impact and expression of reality, which should be met in order to achieve sufficiency.

A further research paradigm which offers a guide to the strategies employed through creative practice is Heuristic Research. Moustakas suggests that "The process of discovery leads investigators to new images and meanings regarding human phenomena, but also to realizations relevant to their own experiences and lives" (1990, p. 9). Heuristic Research is a trial and error approach to the creative process and relates well to stand-up comedy performance.

In order to provide myself with performance opportunities I determined to stage a show in The Melbourne International Comedy Festival. Using myself as a case study I embarked upon writing a fifty minute comedy show, staging it, and then assessing how I benefitted as a performer. In this study, personal reflection regarding the creation of the comedy show, the process of staging it, its challenges and revelations have been explored and analysed using an heuristic immersive method (Moustakas, 1990, p. 9). The analysis of such data cannot be distilled down to simple numbers. Spry (2011) contends that "Our disciplinary roots are grounded in interpretation, a process wrought with the crisis and complexity of representation" (p. 498). Heuristic research employs certain concepts, processes and validation. These include; identifying with the focus of the inquiry, self-dialogue, tacit knowing, intuition, indwelling, focusing, and the internal frame of reference (Moustakas, 1990, p. 15). Immersion in active experience provides a way of discovery, both within the self and in human experience. To put it simply I am telling you my story, I am the research subject and the researcher, reflecting upon the experiences and sharing the insights, emotions, doubts, successes and failures of jumping in the deep end to stage a comedy show at one of the biggest comedy festivals in the world, The Melbourne International Comedy Festival. What was I thinking?

\section{The Melbourne International Comedy festival}

What was I thinking? Did I think I was going to take the comedy world by storm? Yes, yes I did and was I in for a rude awakening? Yes, yes I was. I am a solo performer, an independent artist with no agent, manager or producer therefore all of the logistical processes were my responsibility. Not living in Melbourne and the distance and expense of travelling to Melbourne was a particular disadvantage as I did not have a great knowledge of the venues available for staging a show. The festival organisers provide lists of venues and addresses and it is necessary to make contact and book your own site. Club Voltaire was the name of the venue I chose and it seemed to fit my requirements for size and style but it was not until I visited Melbourne that I realised how far away from the city it was. It was on the outskirts of town, which probably would not have been an issue for a recognized performer with an established audience but in my case this led to the first issue. The position of the 
venue was down a laneway and there was no passing trade and with over three hundred shows to compete with, it was a problem which was very hard to overcome.

Another major concern was marketing. I had posters and flyers and purchased advertising spots in two magazines and in their online version and a spot on a community radio station however I could not afford advertising space in the Comedy festival's official program as the cost was exorbitant. The cheapest was $\$ 3,000$ for a Quarter Page on the back side and the inside page of the back cover was $\$ 15,000$. The cost of staging the show was prohibitive and I am unlikely to have gone ahead with such an event if it was not for my $\mathrm{PhD}$ research. Airfares, accommodation, venue hire, technical support and marketing were all quite costly, costs that were not recovered by ticket sales. Audience numbers were low, over the planned twenty three night run the largest audience was fourteen, there were two nights with no audience and three nights were cancelled at the end of the run due to finances. Audience numbers were, on average, six per night.

With the figures laid out in this stark fashion my show seems to have been a total failure, not a success at all but then again, that depends on the definition of success. While on the one hand I had what I call "fairy story hopes" before going to Melbourne, I also had realistic expectations and as my goal was to gain performance experience, build confidence and develop comedy material I can claim success from the ashes.

\section{Is failure success?}

"Failure is the condiment that gives success its flavour." Truman Capote (cited in Aldrich, 2014)

How do you get ready to do a show in the Melbourne International Comedy Festival? If a young comedian was to ask me this I would suggest different pathways to becoming ready for the Melbourne Comedy Festival. It may be more productive and less expensive to begin by building up material through open mic performances, by joining comedy improvisation groups or by entering the festival newcomer's competition called Raw. There are ways to be involved in the festival through being included in showcases featuring several performers or through the free show venues or by doing spots in other people's shows, which may be an easier process. Nonetheless, for me, the answer to this question, 'How do you get ready to do a show in the Melbourne International Comedy Festival?' Is... 'by doing a show in the Melbourne International Comedy Festival'. The experience, while difficult in many ways, acted as a boot camp providing a concentrated training environment which would not be possible here in Cairns. Failure is an important part of growth and according to George Shapiro, a renowned American manager, it is essential to becoming a great comedian.

Bombing is part of the process of putting a good act together. You have to embrace it. You'll be in pain. You'll feel terrible. I've seen comedians crying after it... but bombing gives you the opportunity of knowing what doesn't work, and then starting new jokes. It's essential that a comedian bombs. Just stay with it, learn from it, and keep doing it. Get back on the horse -- there's a reason for that old cliché. (Shapiro, 2007, 1:05:37)

Through failure I was able to learn what does and does not work and this was also an experience which allowed me to stretch beyond anything I had achieved to date. 
This Melbourne International Comedy Festival show was the catalyst to the creation of a body of stand-up comedy routines and several comic songs. Comedy writing is very much a process of writing and rewriting, trying out a joke or an idea and editing it sometimes on the run, in an improvised situation. Writing from my viewpoint within society I reflect my cultural group, my tribe. I speak for the aging woman and use experiences from my own life to create comedy material. "Performative autoethnography views the personal as inherently political..." (Spry, 2011, p. 498). Spry (2011) insists that it is not merely the expression of one's own personal pain but that it is more than that; it is the connection with larger social issues and "connecting to the politics, pleasure, and pain of other people" (p. 498). Though the experiences I draw from belong to me, they are not mine alone. There are universal themes which exist in my story. Dealing with menstruation, impending menopause, an aging body and diminishing sexuality are shared experiences which others from my immediate group of middle aged women can relate to and using a comedic approach allows for the exploration of embarrassing topics. I am not one dimensional; however, hence my ability to speak from varying facets of my being. I am woman, I am mother, I am academic, I am clown, and I am a member of a complex society and though I am a participant, I am also an observer. Collingwood and Kant agree that through the artist's pursuit of self-knowledge, the whole community can benefit and come to self-knowledge (Graham, 2000, p. 29). Through the expression of my own understandings I aim to have effect on my audience.

I would like to share here an example of some of my writing, a poem written to question the importance placed on, what I consider to be trivial issues within religions.

\section{Trivialities}

If I was god I wouldn't care what you wear upon your head

Or if you ate the bread

Or who you took to bed.... As long as it was consensual

If I was god I wouldn't care how you wear your hair

Or if you say a little prayer

Or how many boobs you choose to bare.... Or cover up, that is up to you

If I was god I wouldn't mind if you chose to be kind instead of going to church

Or if you buy my merch

Or do a Google porn search... I like the ones with a story

If I was god Gina Rinehart would have a kind heart

Clive palmer would get some Karma... from the Dalai Lama

If I was god Rupert Murdoch would have a small.... Bank account

And have to live as a homeless person so he could get some fucking empathy!

But I am not god.... Rupert Murdoch is.

This poem is one example from a body of material which included political ideas, character sketches, personal reflections and humorous songs. Through the performance practice of this material I was able to edit, reconstruct and develop it in accordance with audience reaction and to progress my perceptual understanding of performance situations. 


\section{Self-reflection}

The experiences that you can learn the most from as a practicing performer can be the most emotionally confronting, upsetting and disappointing. Although my experience as a comedian before the Melbourne Comedy Festival had been limited, I had had several successful performances; in fact I had not really had a bad one. Therefore it was confronting to not have a runaway success when I went to Melbourne. This was the big league and I was confronted with many challenges. When I had a reasonable number of people in the audience, the reactions were mostly positive but trying to get a consistent audience was very difficult. I felt totally out of my depth and at times wanted to give up. I was consumed with self-doubt and at times cried from the emotional pain. I was able, though, to overcome these negative emotions by realising how much I was learning and how much experience I was gaining. I was 'paying my dues' and gaining 'war stories' which would build an emotional callus to allow me to continue this pursuit.

This is a heuristic process of trial and error and it felt like I was taking one step forward, two steps back. Taking risks and experimenting in a variety of environments provides opportunities for failure but also offers a chance for success. Without some success and positive responses I don't think I could have continued and the achievement of having an audience pay attention, listen and then laugh is one which is incredibly satisfying and leads to a desire to continue. Therefore I pursued other avenues outside of my own show to gain constructive experiences. Having positive outings contributed to my level of selfassuredness and helped me feel purposeful in the pursuit of performing stand-up comedy. One show I took part in was at a venue nicknamed The Bear Pit, at the Exford hotel, it allowed me to push through anxiety barriers and feel confident in myself as a performer. Double (1997) suggests confidence to be a very important part of comedy performance.

Stand-up comedy is a confidence trick. It's about making the audience believe that you know what you are doing. It's about creating the impression that you are in control of the situation. [...] The confidence trick is an acquired skill and it can take years of experience to be able to pull it off consistently. (Double, 1997, p. 132-133)

In order to acquire this type of confidence, performance opportunities and experiences like those provided by an environment such as the Melbourne Comedy Festival are required.

\section{Conclusion}

Staging this show at the Melbourne International Comedy Festival afforded me the chance to test out material and to repeat routines over many nights so as to feel at ease on the stage. It allowed me to understand the challenges of taking on the pursuit of expertise as a stand-up comedian. Performing at this festival also allowed me to be immersed in the environment of the city, alive with comedy and opportunities. It gave me the possibility of meeting other comedians, seeing many shows and having the prospect to perform in show case events and tackle challenging audiences and situations. Although, on the surface the figures from the show would have you believe it was not very successful, the experience and expertise gained from the process were very empowering. I would liken it to having a baby, people can tell you what it is like but you will never really know until you have one yourself. According to 
Goldman; "Good judgment comes from experience, and experience comes from bad judgment" (qtd. in A. Williams 1). It may well have been questionable judgement to do this show but I have gained invaluable experience. Was it worth it? For me, yes it was.

\section{Works Cited}

Aldrich, M. (2014). A Shade of Failure: A Literary Rivalry. In: The gad about town. Retrieved from: https://thegadabouttown.com/2014/11/04/a-shade-of-failure-aliterary-rivalry/

Blainey, G. (2001). The tyranny of distance, revised edition. Sydney: Pan Macmillan Australia Pty Ltd.

Chang, H. (2007). Autoethnography as Method: Raising Cultural Consciousness of Self and Others. In: G. Walford (Ed.), Methodological Developments in Ethnography (Studies in Educational Ethnography, Volume 12, pp. 207-221. Emerald Group Publishing.

Denzin, N.K. (2003). Performance ethnography: Critical pedagogy and the politics of culture. California, CA: Sage Publications.

Double, O. (1997). Stand-up: On being a comedian, London: Methuen, Random House.

El-Husseini, E (2010). Open Mic Night Tips, WatchMojo.com [Youtube video]. Retrieved on 12 September 2015.

Ericsson, K.A. (1996). The road to excellence: The acquisition of expert performance in the arts and sciences, sports and games. Mahway, NJ: Lawrence Erlbaum Associates.

Ericsson, K.A., Krampe, R.T., \& Tesch-Romer, C. (1993). The role of deliberate practice in the acquisition of export performance". Psychological Review, 100(3), 363-406.

Friedlander, J. (2010). Advice for comedians, RBTV interview. Retrieved on 12 August 2015.

Gladwell, M. (2008). Outliers: The story of success. New York, NY: Little, Brown and Company.

Graham, G. (2000). Philosophy of the arts: an introduction to aesthetics. New York, NY: Routledge.

Seinfeld, J. (2002). Jerry Seinfeld: Comedian [Documentary], New York: Bridgnorth Films.

Kellman, P.J. \& Garrigan, P. (2009). Perceptual learning and human expertise. Physics of Life Reviews 6, (2009): 53-84.

Kolb, D.A. (1984). Experiential learning: Experience as the source of learning and development. Englewood Cliffs, NJ: Prentice Hall. 
Maron, M. (2015). On bombing in comedy clubs, AOL BUILD [Youtube video]. Retrieved on 12 August 2015.

Moustakas, C. (1990). Heuristic research: design, methodology, and applications. Newbury Park, CA: SAGE Publications.

Reed-Danahay, D.E. (Ed.). (1997). Auto/Ethnography: Rewriting self and the social, Oxford: Berg.

Russo, A. (2009). Malcolm Gladwell: In Outliers, Gladwell looks at how genius is made. What can educators take away? Instructor, May/June, 64.

Searle, R. (1991). Artist in the tropics: 200 years of art in North Queensland. TownsvillePerc Tucker Regional Gallery.

Shapiro, G. (2007). George Shapiro interview part 1 of 2, EMMYTVLEGENDS.ORG [YouTube video]. Retrieved on 16 July 2015.

Sparkes, A.C. (2002). Autoethnography: Self-indulgence or something more? In: A.P. Bochner \& C. Ellis (Eds.), Ethnographically Speaking:Auto- ethnography, Literature and Aesthetics, pp. 209-232. Oxford: Altamira Press.

Spry, T. (2011). Performance autoethnography: Critical embodiments and possibilities. In: N.K. Denzin \& Y.S. Lincoln (Eds.), The Sage handbook of qualitative research, pp. 497-511. California: Sage Publications.

Williams, A. (2013, November 5). Healthcare Workers are Only Human. Alaska Highway News. Retrieved from ProQuest on 12 August 2015.

Williams, C. (2013). Career development and contemporary visual artists: An investigation of Cairns Australia, etropic, 13, 1-9. 